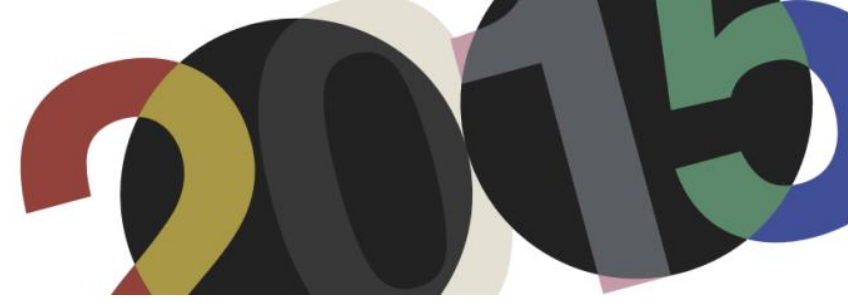

DOI: http://dx.doi.org/10.4995/LC2015.2015.957

\title{
Le Corbusier and Ariadne
}

\section{A. Fonti}

Dipartimento di Architettura Design Urbanistica, Università di Sassari

\begin{abstract}
From a letter dated 1913 to W. Ritter in which he described the "erotic obsession" which had caused him to depict the statue of the Sleeping Ariadne in the gardens of Versailles as a scantily-clad odalisque in the painting entitled La Versailles du Grand Turc, up to his last graphic project of 1964 entitled "Nassaince du Minotaure II", the "private mythology" of Le Corbusier's works was dominated by Minoan-Cretan mythology, to the point that the bull symbol became the unifying principle of his entire pictorial, plastic and architectural work. Dozens of Le Corbusier's architectural projects include the theme of the labyrinth. The "main ouverte" and Ariadne - la Licorne were intended to "join up" from afar Chandigarh with the Bhakra dam. For the dam Le Corbusier designed architectural elements and he planned to install a copy of the "Ariadne" sculpture, similar in size to the "open hand" at Chandigarh. The Chandigarh-Bhakra complex - the planned city and the hydroelectric infrastructure - was the realization of the global post-war reconstruction plan, an approach devised by Le Corbusier together with the UN'S CIAM, based on the model of the TVA, the New-Deal Federal Agency, which had planned the development of the most backward area in the States starting from hydropower generation. The story is encrypted on the back of the tabernacle at Ronchamp.
\end{abstract}

Resumen: De una carta de fecha 1913 a W. Ritter en el que describía la "obsesión erótica", que le había hecho representar la imagen de la Ariadna dormiente en los jardines de Versalles como una odalisca desnuda en el cuadro titulado La Versalles du Grand Turc, hasta su último proyecto gráfico de 1964 titulado "Nassaince du Minotaure II", la "mitología privada" de las obras de Le Corbusier fue dominado por la mitología minoico-cretense, hasta el punto de que el símbolo del toro se convirtió en el principio unificador de toda su obra pictórica, plástica y arquitectónica. Decenas de proyectos de arquitectura de Le Corbusier incluyen el tema del laberinto. La "main ouverte" y Ariadna - la Licorne estaban destinadas a unirse de lejos Chandigarh con la presa de Bhakra. Para la presa Le Corbusier diseñó elementos arquitectónicos y que planeaba instalar una copia de la escultura "Ariadna", similar en tamaño a la "mano abierta" en Chandigarh. El complejo de ChandigarhBhakra - la ciudad planificada y la infraestructura hidroeléctrica - fue la realización del plan mundial de la reconstrucció posguerra, un enfoque ideado por Le Corbusier, junto con el CIAM de la ONU, basado en el modelo de la TVA, el New-Deal Agencia Federal, que había planeado el desarrollo de la zona más atrasada de los Estados Unidos a partir de la generación de energía hidroeléctrica. La historia está cifrada en la parte posterior del tabernáculo en Ronchamp.

Keywords: Minoan-Cretan mythology; Ariadne; Taureaux; hydropower; Chandigarh; Ronchamp.

Palabras clave: Mitología minoico-cretense; Ariadna; Taureaux; energía hidroeléctrica; Chandigarh; Ronchamp. 


\section{Introduction}

From the publication of the Tate Dossier ${ }^{1}$, the project for the 1958 exhibition of the paintings known as 'Bulls' at the Tate Gallery, which confirmed Le Corbusier's intention of unifying his entire pictorial production in the 'sign of the bull', it became evident to what extent Minoan-Cretan mythology was to dominate the 'private mythology' of Le Corbusier and how it marked symbolically his whole 'plastic' production: painting, sculpture and architecture.

Le Corbusier himself recognised an unconscious phase of dominion of the 'sign of the bull' over his imagination, from the 1920s to April 1952, the date of his return from his third trip to Chandigarh and completion of his projects for the Capitol complex and for the main ouverte. Subsequently, in the conscious phase he re-painted 'retroactively' the Purist still-life paintings of the 1920s, bringing out from them the sign of the bull, and renaming them intentionally Taureaux. Thus he started the series of 'bull' paintings, which he would continue to the end of his life (Fig. 1).

An early sign of the powerful influence of the Minoan myth on Le Corbusier's imagination is found in his 1913 letter to William Ritter ${ }^{2}$, in which he confessed his erotic infatuation with the statue of the sleeping Ariadne in the gardens of Versailles ${ }^{3}$ (Fig. 2), according to the myth abandoned in sleep by Theseus on the small island of Naxos during his return trip from Crete to Athens. A strong erotic impulse drew him to depict her in colour in the nude, unclothed and as enticing as a Rubens odalisque in the gouache he entitled Versailles du Grand Turc ${ }^{4}$ (Fig. 3). Fifty years after this 'love at first sight', one year before his death, a large copy of the portrait of Ariadne still hung above the revolving access door to the Le Corbusier Centre in Zurich ${ }^{5}$ (Fig. 4). Le Corbusier's vision of the feminine and eroticism is marked by the Dionysian, coloured and Bacchic elements of his Turkish depiction of the Versailles statue, itself a 1600s copy of a Hellenic marble of the second century AD.

The feminine-Dionysian combination is typical of Le Corbusier's cultural background. He was deeply influenced by Schurè's Le Grands Initiés. Esquisse de l'histoire secrète des religions ${ }^{6}$, which he received as a gift from his teacher L'Eplattenier, who considered him his best pupil and led him on the path of architecture. Schurè's book outlined effectively the mythological world of Ancient Greece on the basis of the oppositions between Solar-Apollonian-male-mountain on the one hand and lunar-Dionysian-female-valley bottom on the other, the place where waters flow, the delta of the river and of Venus.

\footnotetext{
${ }^{1}$ Coll, Jaime: "Le Corbusier. Taureaux: an analysis of the thinking process in the last series of Le Corbusier's plastic work", in Art History, vol. 18, n. 4. December 1995, Oxford and Cambridge (Mass): Blackwell Publisher, pp. 537-567.

2 Jencks, Charles: Le Corbusier and the Continual Revolution in Architecture, New York: Monacelli Press, 2000; italian ed. Le Corbusier e la rivoluzione continua in architettura, Milano: Jaka Book, 2002, p. 84.

${ }^{3}$ Corneille Van Cléve, Ariane endormie, 1684-1688.

${ }^{4}$ Le Corbusier, Un Versailles du Grand Turc, (FLC 4097).

${ }^{5}$ Le Corbusier, Arianne, (FLC 4 November 1963).

${ }^{6}$ Schuré, Edouard: Le Grands Initiés. Esquisse de l'histoire secrète des religions, Paris: Perrin et Cie, 1889, passim.
} 


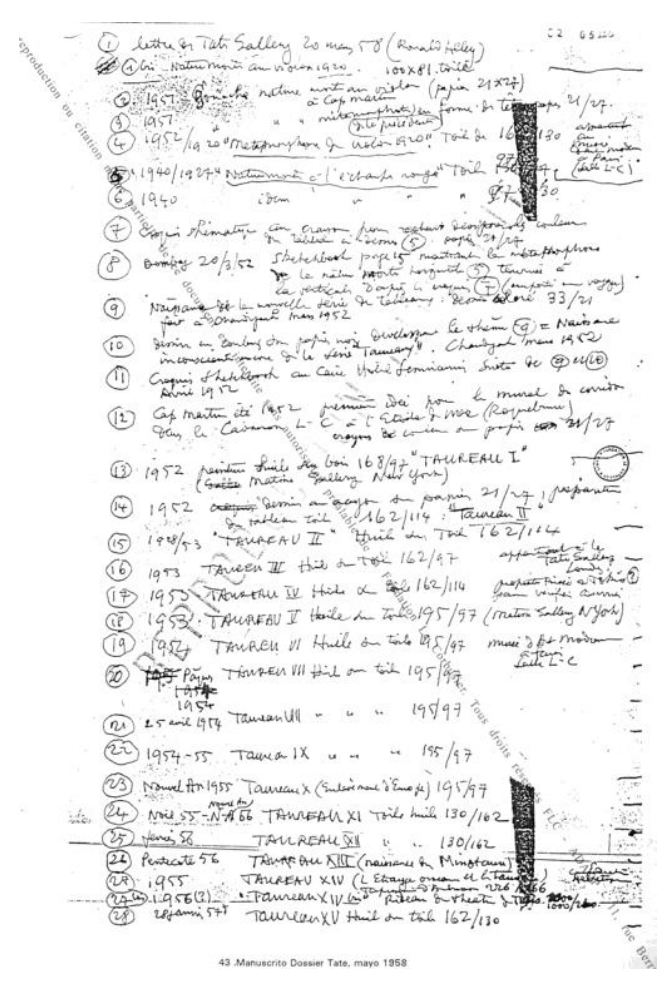

1. Le Corbusier, Dossier Tate, 1958 (FLC C2-05 100, (OFLC-ADAGP).

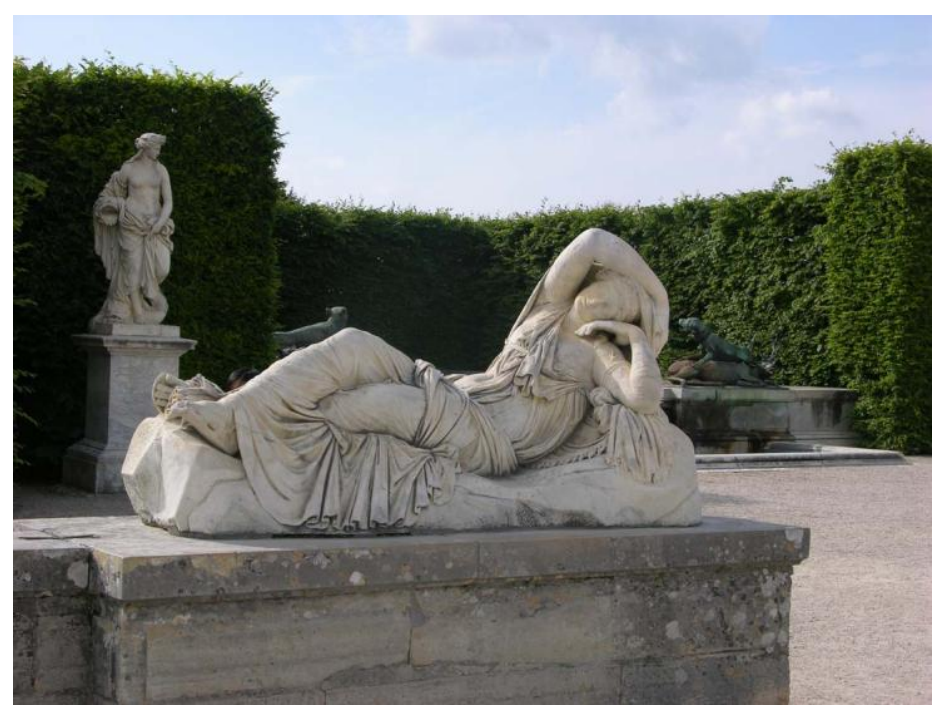

2. Corneille Van Cléve, Ariane endormie, 1684-1688, (AF Archives). 


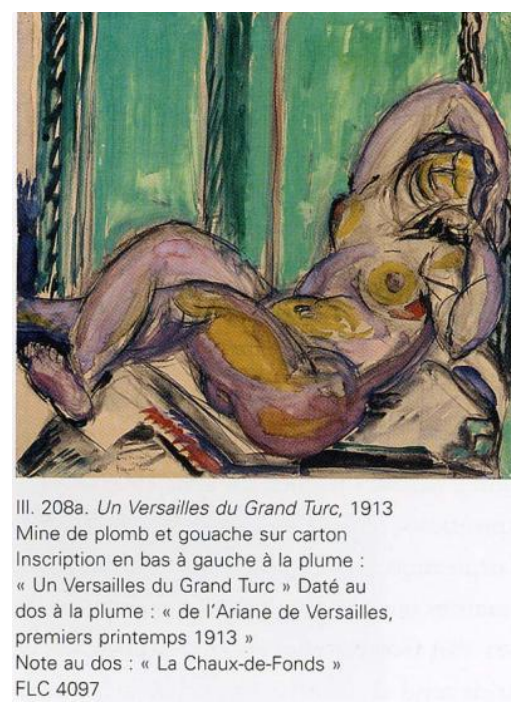

3. Le Corbusier, Un Versailles du grand Turc, 1913 (FLC 4097, @FLC-ADAGP)

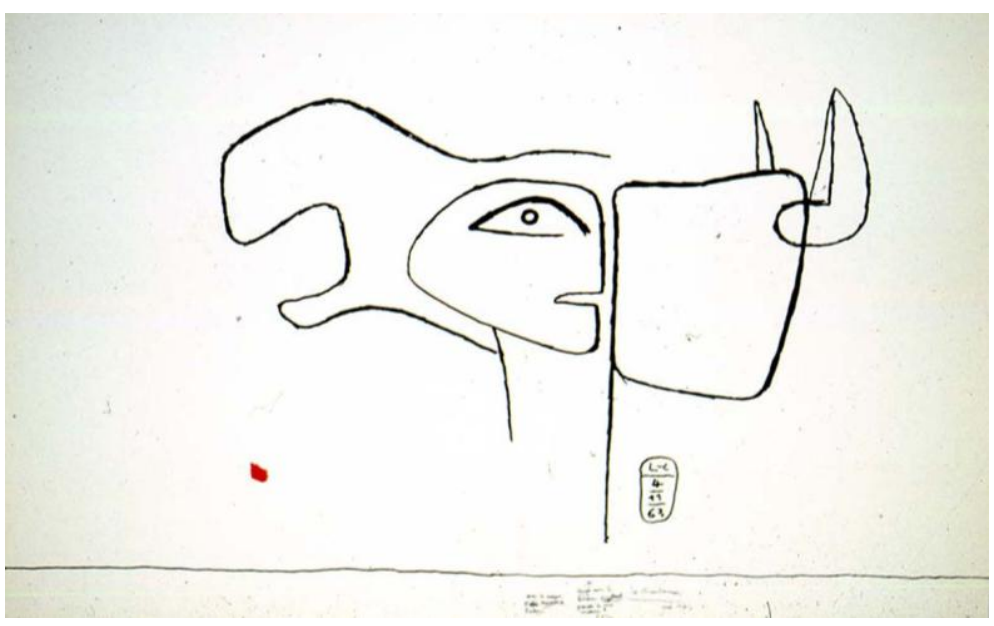

4. Le Corbusier, Arianne, 4 November 1963 (@FLC-ADAGP)

\section{Ariadne, Dionysius and the Labyrinth}

In 1913 the mythological connection between Ariadne and Dionysius (hence the continuity between Cretan Minoan mythology and Greek mythology) was still obscure, as shown in the question posed by Nietzsche: "Who knows, but, me, what Ariadne is!"7.This is an essential question (answer), because if we ignore Ariadne we ignore Dionysus, who met Ariadne deserted at Naxos, and if we ignore Dionysus we ignore the 'origins of tragedy' and hence of classical Greek culture.

The question of Ariadne's identity was later answered by the mythological studies of Kerényi on the Dionysian relationship between Crete and Athens and between Ariadne and Athena. In parallel, it was answered by the archaeological studies in Crete, which shed light on the ruins of the Minoan labyrinths and outlined the whole of Crete's 'Palatial' civilisation. This was marked by the architectural and urban-temple design of the labyrinth, which was centripetal. This design is typical of the island civilisation in the Cyclades and Crete, as opposed to

\footnotetext{
${ }^{7}$ Nietzsche, Friederich: Ecce Homo, Leipzig: Insel Verlag, 1908; italian ed. Ecce Homo, Milano, Adelphi, 16th ed., 2012; Kerényi, Karl: Labyrinth-Studien, Zurich: Rhein-Verlag, 1950; italian ed. Nel labirinto, Torino: Boringhieri, 1983, p. 167.
} 
the mainland Mycenaean temple type, the oriented megaròn which gave rise to the Parthenon. This was finally confirmed by the translation of 'linear b' writing starting from 1952.

In short, Kerényi's interpretation, developed in the 1930s and confirmed by archaeological studies identifies Ariadne as the greatest Cretan divinity, the 'Lady of the Labyrinth'. A double divinity, Arihagne and Aridela, celestial and subterranean, lunar and bull-like, 'the purest' in the night and 'the brightest' in the underworld, double as the labyrinth itself is double, identified with the central courtyard which marked the palace-cities of this 'neo-palatial civilisation' as a space dedicated to the fundamental rite in honour of Ariadne, the ecstatic dance in accordance with the steps guided by the swastika shape of the maze - the symbolic shape of the labyrinth - etched into the flooring.

The proper name of the upper labyrinth is the 'palace of the two axes', etymologically because it was built with the labris, the two-headed axe which was the symbol of the highest priesthood, that of Daedalus, architect of the labyrinth and of the dance which the labyrinth itself is: "Ariadne danced the labyrinth" labyrinth, 'the palace of the viscera', illuminated by Aridela and inhabited by the Minotaur, whose name is Asterion, 'the starry one', the monster with the head of a bull but dotted with stars, which prompted Gide's Theseus to say: "le monstre était beau" (the monster was beautiful). The other rites of the cults of Ariadne are the taurocatapsia, the 'great leap' of the bull, and the propitiatory offering of honey and wine. The archaeological findings which shed light on religious and mythological practices, above all on the culture of wine and dance, placed the divinities of Ariadne and Dionysius at the centre of Minoan-Cretan civilisation and connected this civilisation directly with Athenian civilisation ${ }^{10}$. Theseus' desertion of Ariadne at Naxos, half way between Crete and Athens, before setting off to found Athenian democracy, represents the need to first remove Dionysian femininity, which by its Bacchic nature could subvert sexual taboos and hence disrupt all social order.

\section{Le Corbusier: Daedalus and La Licorne}

These themes were explored in depth in Le Corbusier's cultural circle: consider his relationship with Christian Zervos, author of books on pre-Cycladian archaeology and editor of the Cahiers $d$ 'art, the art journal of the avant-garde movements in which Le Corbusier published an account of his trip to Athens. Or consider his collaboration with the review Minotaure, which focused the attention of the surrealist movement on primitivism, blending archaeology, ethnology and Jungian psychology in the search for a new unconscious, pre-classic universality.

At the same time as the first issues of the review came out, on his return from Greece, Le Corbusier inaugurated his own Parisian house-atelier with an exhibition entitled 'L'art primitive dans la maison d'aujourd'hui' (primitive art in today's home) where he exhibited among ethnic and Cubist works the gypsum copy of a Greek kriophoros which he coloured with violent brush strokes (Fig. 5). This was his way of linking primitivist ethnic universality to avant-garde/neo-Humanistic art in the sign of a classic yet not Apollonian statute, but rather Dionysian, as the numen protecting the new home of Corbusier and Yvonne ${ }^{11}$

\footnotetext{
${ }^{8}$ Calasso, Roberto: Le nozze di Cadmo e Armonia, Milano: Adelphi, 2005, p. 74.

${ }^{9}$ Gide, André: Theésée, Paris: Gallimard, 1947; italian ed. Thésée, Bari: Palomar, 1996, p. 100.

${ }^{10}$ Kerenyi, Karl: Dionysos. Urbild des unzerstörbaren Lebens, München-Wien: Langen-Müller, 1976; italian ed. Dioniso, Milano: Adelphi, 1992, passim.

${ }^{11}$ Le Corbusier: Les arts dits primitifs dans la maison d'aujourd'hui, exhibition, 3-13 july 1935, Rue Nungesser et Coli 24, $\mathrm{XVI}^{\circ}$ (FLC C1-5 139-144).
} 
Mogens Kustrup has demonstrated that Le Corbusier attributed to Yvonne a Minoan mythological identity. He depicted her as Pasiphae - Ariadne - Icone - the Licorne, figures depicted in the frescoes of the Swiss Pavilion and the petit cabanon, and in the Poème de l'angle droit ${ }^{12}$ and a host of sketches, designs, paintings and sculptures. Yvonne's Cretan mythological identity as the Licorne would appear to be matched by that of Le Corbusier as the Bull - Theseus - 'the Athenian' - Daedalus ${ }^{13}$.

The double and multifaceted character of Ariadne allows her to be identified in more than one woman, firstly in Josephine Baker, a protagonist of the deep cultural impact produced by the primitive dances of the Revue Negre

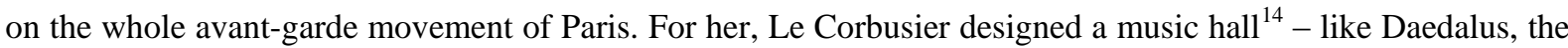
architect of the Ariadne's dance - and he depicted her in pictures and sculptures such as La Danseuse ${ }^{15}$, the primitive dancer, the black manifestation of Ariadne.

The close link between Le Corbusier-Daedalus and Ariadne was repeated in his Indian experience, where Ariadne took the identity of Minnete Da Silva, the cosmopolitan Singhalese grande dame, a London architect, who introduced him to the upper echelons of politics and the enlightened entrepreneurship of India involving him in the foundation and activities of the Marg (Modern architecture research group) an avant-garde group and journal of modern Indian architecture, sponsored by businessmen such as Tata. Le Corbusier celebrated the meeting in a note in his cahier in connection with his re-reading of Gide's Theseus during a flight from Geneva to Delhi in 1958: "J'ai eu le temps de lire Thésée (Gide) Ariane et Dédale + Marg. Et avoir change d'atmosphère. Etre // jeune, à nouveau!!"16.

The previous year Le Corbusier dedicated to Yvonne, as she lay dying, the monologue of the ghost of Icarus in Gide's Theseus together with the Iconostase ${ }^{17}$ (Fig. 6), and his draft plans for Le poème de l'angle droit (Poem of the right angle), which were the icons of his imaginary autobiography but also the greatest homage to Yvonne-Icone: Yvonne as the 'angel droit', the other title of the Poème, sacred as the Madonna in orthodox icons (Fig. 7). The analogy 'angel'/'angle' was not new in the Parisian avant-garde movement, where Jean Cocteau expressed it: "En hébreu le mot ange et le mot angle sont synonymes. La chute des anges symbolise, dans la Bible la chute des angles, c'est-à-dire, la crèation tout humaine d'une sphère conventionnelle,"18.

But it is above all the Licorne, a naked, winged female figure with the head of a one-horned goat, depicted in the main ouverte from which it is born and which guards it in accordance with Mallarmè's verse "garder ton aile dans ma main" "19 , which sums up the complexity of the meanings Le Corbusier attributes to this figure, making it the leading character of the Poème (Fig. 8). Thus an angelic winged figure; with the head of a goat, hence Dionysian, but female and unique, non-reproducible just as the Licorne, the figure which seems to be lacking in the Apollonian Olympus of Athens but which, according to Kerényi's studies, is present in the mythological

\footnotetext{
${ }^{12}$ Le Corbusier, Poème de l'Angle Droit, Paris: Éditions Tériade, 1955.

${ }^{13}$ Kustrup, Mogens: "La peinture du silence", in Massilia, Sant Cugat del Vallés (ES): Associaciò d'idees. Centre d'investigacion Estètiques, 2005, pp. 156-169.

${ }^{14}$ Casali, Valerio: "Le Corbusier, Josephine Baker e il Music-Hall”, in Massilia, Sant Cugat del Vallés (ES): Associaciò d'idees. Centre d'investigacion Estètiques, 2004, pp. 136-151.

${ }^{15}$ Le Corbusier, La danseuse, scluptures (FLC 104, 215, 3398, 6379).

16 "I had time to read Theseus (Gide) Ariadne and Daedalus + Marg. And the atmosphere has changed. Being young, once again!!” (author's translation), Kustrup: “La peinture du silence”, p. 160.

${ }^{17}$ Le Corbusier, Carnet Nivola I, (FLC W1-8 113).

18 "Angel and Angle are synonyms in Hebrew. The fall of the angels can thus be translated as a fallo of the angles. The fall of the angles thus means: ideal sphere, disappearance of Divine Force, apparition of the conventional, the human" (author's translation), Cocteau, Jean: "Le secret professionnel”, in Poésie critique, vol. 1, Paris: Gallimard, 1959, p. 24.

${ }^{19}$ Mallarmé, Stéphane: Autre èventail (de Mademoiselle Mallarmé), 1884.
} 
syncretism which links in continuity Ariadne to Athena through the figure of Dionysius, who met Ariadne (of whom he was both spouse and son) when she reawakened after being abandoned in Naxos.

And it is in Phidias' statue of Athena Parthenos - the divinity of the Parthenon - that we can identify the model of the Licorne held in the open hand. This model is found in the right hand of Athena which holds the small winged figure of the Athena Nike, symbol of the victory conferred by Athena Parthenos on the winners of the Games. By 'translating' the small Athena Nike into the Licorne, Le Corbusier moved symbolically beyond the Neo-Classical winckelmanian 'Apollonian' vision of the Greek world, rediscovering its ancient Dionysian and Cretan origin, identified with the figure of Ariadne-La Licorne. And this was the sense of his discovery of Greece as a colourful, sound-filled and 'acoustic' world, lively and vital, during his trip to Athens with the CIAM in $1933^{20}$.

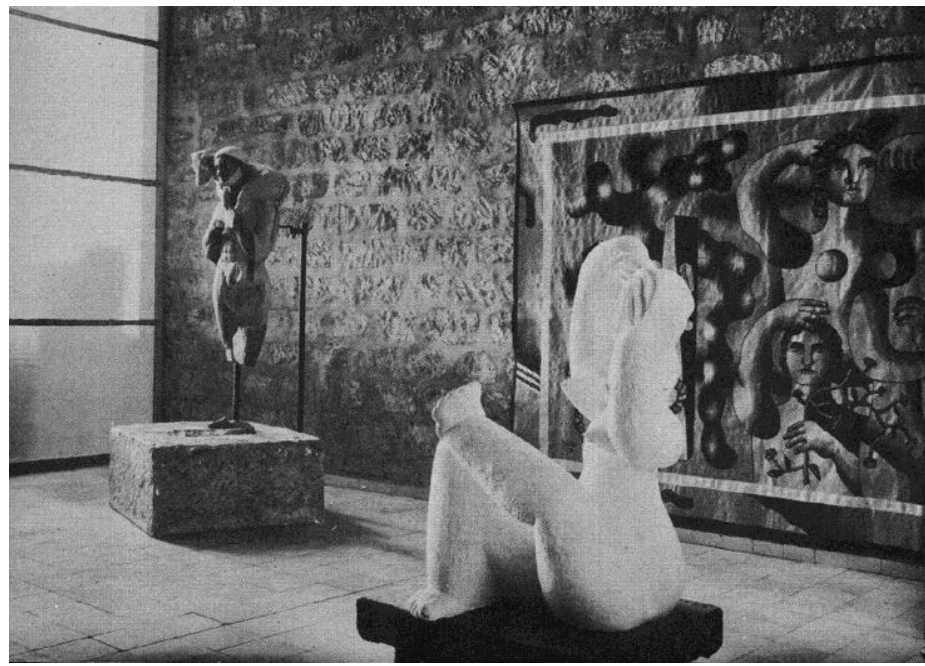

5. Le Corbusier, Les arts dits primitifs dans la maison d'aujourd'hui, exhibition, 3-13 july 1935, 24NC, (FLC C1-5 139-144, (OFLC-ADAGP).

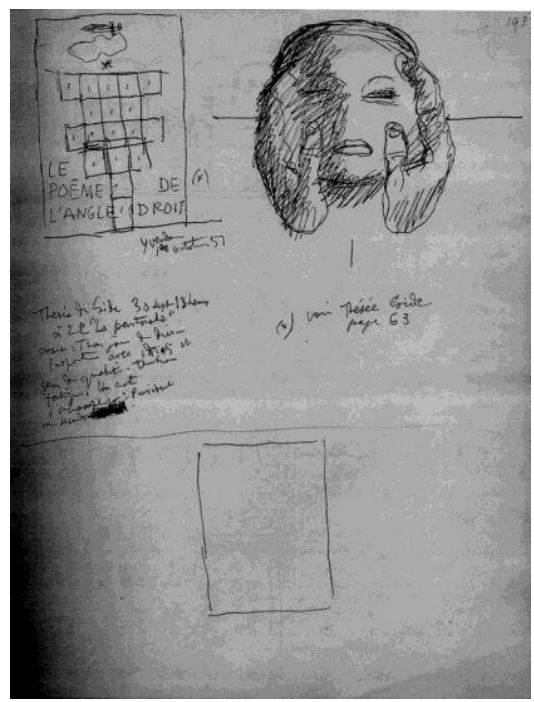

6. Le Corbusier, Yvonne dying, Carnet Nivola I, (FLC W1-8 113, @FLC-ADAGP)

\footnotetext{
${ }^{20}$ Le Corbusier, “En Grèce, à l'échelle humaine”, in Le voyage en Gréce, Paris: Cahiers périodiques, 1939.
} 


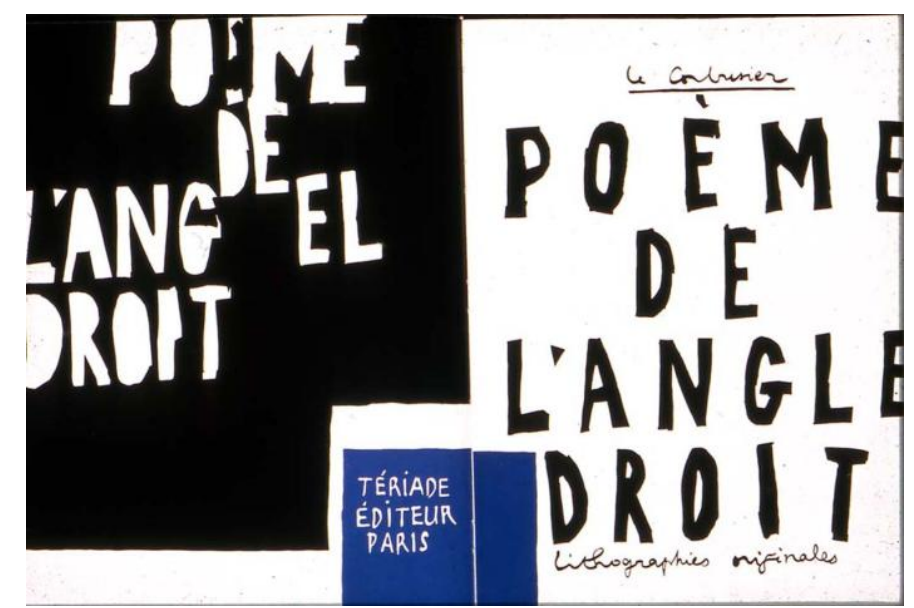

7. Le Corbusier, Poème de l'angle droit, 1955.

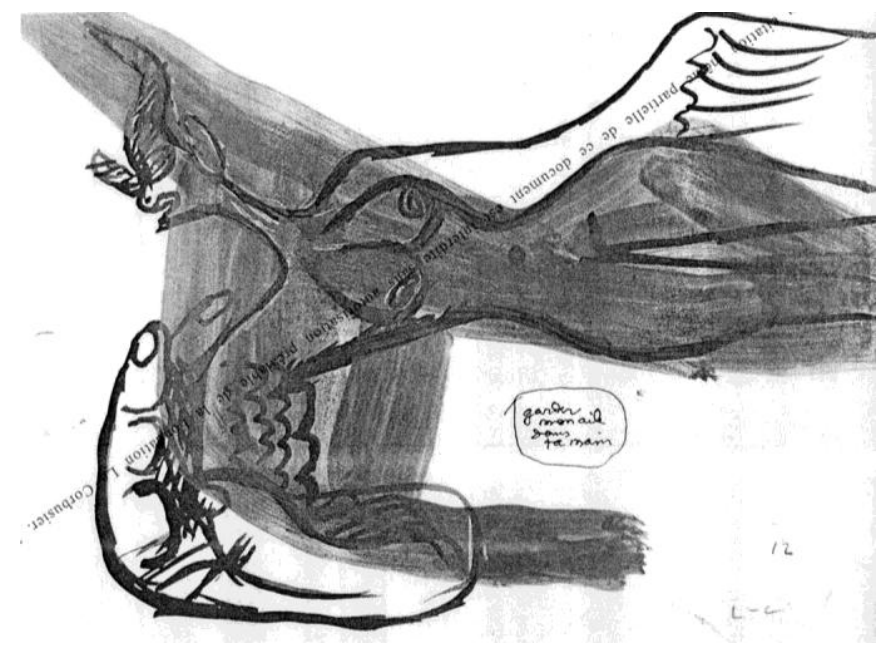

8. Le Corbusier, main ouvert e Licorne (@FLC-ADAGP).

\section{The signe du taureau and architecture: Chandigarh and Ronchamp}

Thus, While the Minoan-Cretan mythological imagination, 'the sign of the bull' marked Le Corbusier's entire 'private mythology' as expressed in his paintings and sculptures, it is only in the 'conscious phase' that this vision also spread to his architecture, as is shown by the enigmatic drawing entitled 'le dénouement du meandre': the hollow between the horns, the sign of the bull, is the principle of the impluvium necessary in flat roofs as opposed to the principle of the displuvium of the pitched roof shown in the sketch of the roof of the Parthenon $^{21}$ (Fig. 9).

In unveiling the meander, the façade of the Parthenon with its pitched roof shows the wrong direction out of the labyrinth and is opposed to the cross section of the projecting roof of Ronchamp and to the plan for the Governor's Palace of Chandigarh with its concave roof with impluvium, being the right direction for 'revealing the meander'. But it is in the façade of the Parliament that the 'sign of the bull' 'translates' the pitched roof of

\footnotetext{
${ }^{21}$ Le Corbusier, Entre-Deux (FLC 3.1.1957).
} 
the Parthenon into the pronaos, with eight "columns" like the Parthenon but concave and evidently dominated by the 'sign of the bull' and the function of the impluvium (Fig. 10).

The principle of the architectural impluvium, 'the unveiling of the meander' becomes the analogue of the 'law of meander', natural and universal, which shapes the delta of rivers and the fluvial terrain of the territories which Le Corbusier always noted accurately as he flew over them ${ }^{22}$. The two dimensions came together in the parallel and mutually-influencing events of Chandigarh and of the Bakrha dam (for the dam, Le Corbusier sought and obtained a commission for some architectural features) (Fig. 11).

The interest of Le Corbusier for fluid dynamics in relation to the construction of river dams is documented starting from 1940 by his exchanges with Engineer Coyne, the designer of the French dam of Chastang in accordance with innovative methods which combined the dam itself and the machinery for the production of hydro-electric power (Fig. 12). The drawings of the waterfall produced by the dam's floodgates were to become the model for the 'cascade' produced by the gargouille of the chapel of Ronchamp, whose dynamics regulates all measurements of the chapel's impluvium roof (Fig. 13).

Le Corbusier's interest in dam architecture on the scale of territorial and urban planning became much stronger during his mission to the US in 1946, when he attempted to involve in his plan for post-war reconstruction and territorial and urban planning on a global scale the Tennessee Valley Authority (TVA), the 'new deal' Federal Agency which had planned the exploitation of the natural resources and territorial and urban layout of the whole Tennessee-Mississippi-Missouri basin, starting from the development of hydro-electric resources with the construction of 11 dams and the project for the construction of some twenty new towns. The TVA's refusal of any involvement in the global project contributed to the failure of the project for the UN headquarters building, which Le Corbusier had envisaged as the centre of a world administrative capital from which the UN's CIAMs would have directed global reconstruction and planning, the most ambitious and Utopian of his projects ${ }^{23}$.

After the failure of the global government of the UN and the beginning of the Cold War with the division of the world into two opposing blocs, the project for the complex of Chandigarh, the foundation city and new capital, and for the Bhakra dam applied the TVA's planning model to India - the leading nation of the few non-aligned countries. On the summit of the Bhakra dam ${ }^{24}$, Le Corbusier planned to install a copy of the sculpture entitled Eau, Ciel, Terre ${ }^{25}$ of the same huge size as the main ouverte of Chandigarh. This sculpture will evolve into a new sculpture named $\mathrm{La} \mathrm{mer}^{26}$ which is the plastic translation of the numerous series of drawings that begin with the sketch entitled Naissance des Taureaux ${ }^{27}$, the fundamental graphic theme of most of Taureaux ${ }^{28}$ (Fig. 14). The symbol main ouverte-la licorne which he had placed on the cover of the Poesie sur Algier ${ }^{29}$ (Fig. 15) evolves between Bhakra and Chandigarh in what that union had generated, the naissance of Taureaux.

\footnotetext{
${ }^{22}$ Sanchez-Pombo, Marina: "La arquitectura de los fluidos. Le Corbusier y los rios”, in Massilia, Sant Cugat del Vallés (ES): Associaciò d'idees. Centre d'investigacion Estètiques, 2004, pp. 48-69.

${ }^{23}$ CIAM document, (FLC U3-13 84)

${ }^{24}$ Le Corbusier, Carnet L 50, 8.12.1957 (FLC W1-3 1088).

${ }^{25}$ Le Corbusier, Eau, Ciel, Terre, 1954 (FLC 14).

${ }^{26}$ Le Corbusier, La mer, 1963 (FLC 36).

${ }^{27}$ Le Corbusier, Carnet K 43, "10 aout 1952, repeint 1956", (FLC W1-3 652).

${ }^{28}$ Jornod, Naima; Jornod, Jean-Pierre: Le Corbusier. Catalogue raisonné de l'oeuvre peint, vol. II, Milan: Skira, 2005, pp. 874-889.

${ }^{29}$ Le Corbusier, Poésie sur Alger, Paris: Éditions Falaize, 1950.
} 
At the same time, the construction of Ronchamp synthetized in a monument Le Corbusier's private mythology decreeing the 'crisis of Rationalism, ${ }^{30}$. 'The sign of the bull', the architectural principle of the impluvium roof, clearly acquired the character of the 'law of the meander', transforming the roof in the hollow of a river delta which collects the waters and directs them to the gargouille which is shaped according to the 'sign of the bull', but also to the 'law of the meander': the slope of the roof is calculated from lower to upper "comme une onde croissante, 31 , opposed to the natural gravity of the descending pluvial wave (Fig. 16).

The 'cascade' produced by the gargouille falls into the fountain which contains elementary geometric volumes similar to natural crystals (crystals that for Luca Pacioli testified to the presence of the "Divina Proporzione" in nature) in the point where the wall swells externally, matching the internal confessional, as if in the place of 'confession' the architecture had been fecundated and mysteriously made 'full of grace' (Fig. 17).

On the north side, the two cement canopies frame the entrance, drawing in a plastic form the 'sign of the bull' just as the merlons on the Cretan palace of Knossos, the archaeological site of Ariadne's mythological labyrinth: the entry to the Ronchamp church is made through that sign (Fig. 18).

Mogens Kustrup had noted that the pagan and sexual meaning of those references could jar rather blasphemously with the dedication of the Chapel to the Virgin. Indeed, the figure of Mary, the small wooden statue placed in the recess on the façade, which connects the inside with the outside of the church, appears as a mysterious entity: from the outside it is in full sunlight, but is seen from behind, since she faces inside. From the inside she is backlit and only her contour is visible, set among the glass-concrete elements forming the shiny constellation of the Capricorn ${ }^{32}$.

But it is on the back side of the tabernacle, the hidden side of the 'house of God', that the mystery seems to reveal itself as enriched by other meanings: set opposite the front image of the Agnus dei qui tollis peccata mundi, there is a male figure, with a tree-like design ${ }^{33}$, appearing to behold a water horizon broken into two levels, the section of a watershed ending with the sea, blocked by a dam which stands against tall mountains topped by a sky painted in the fundamental colours which should have been the colours of the main ouverte pointing towards the Himalaya. Above, an explosion of red light: the dawn depicted by Le Corbusier in his carnets during a flight to Chandigarh ${ }^{34}$. Higher still, the blue sky is topped by the shape of the cross which, in the side facing the congregation, shows the crucifix above the agnus Dei (Fig. 19).

\footnotetext{
${ }^{30}$ Stirling, James: "Ronchamp; Le Corbusier's Chapel and the Crisis of Rationalism", in Architectural Review, 119, March 1956, pp.155-161.

31 “as a growing wave”, Le Corbusier, Textes et dessins pour Ronchamp, Paris: Éditions Forces Vives, 1965, p. 39

${ }^{32}$ Kustrup: "La peinture du silence", pp. 164-5.

${ }^{33}$ Le Corbusier, Textes et dessins pour Ronchamp, 1965, p. 8.

${ }^{34}$ Le Corbusier, Carnet J37, (FLC W1-3 361-362).
} 


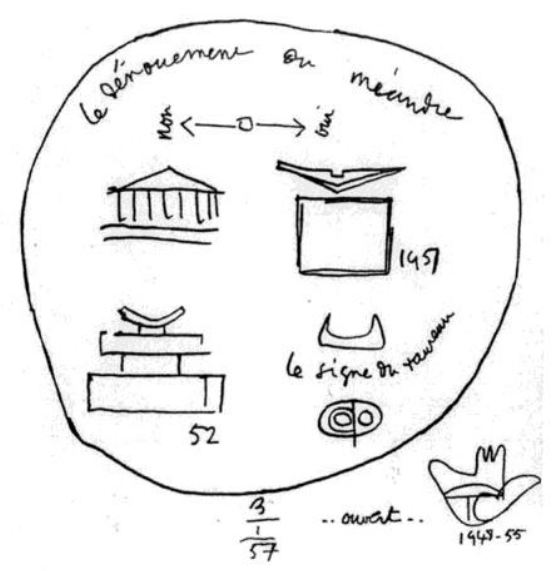

9. Le Corbusier, le dénouement du méandre, 3 January 1957, (@FLC-ADAGP)

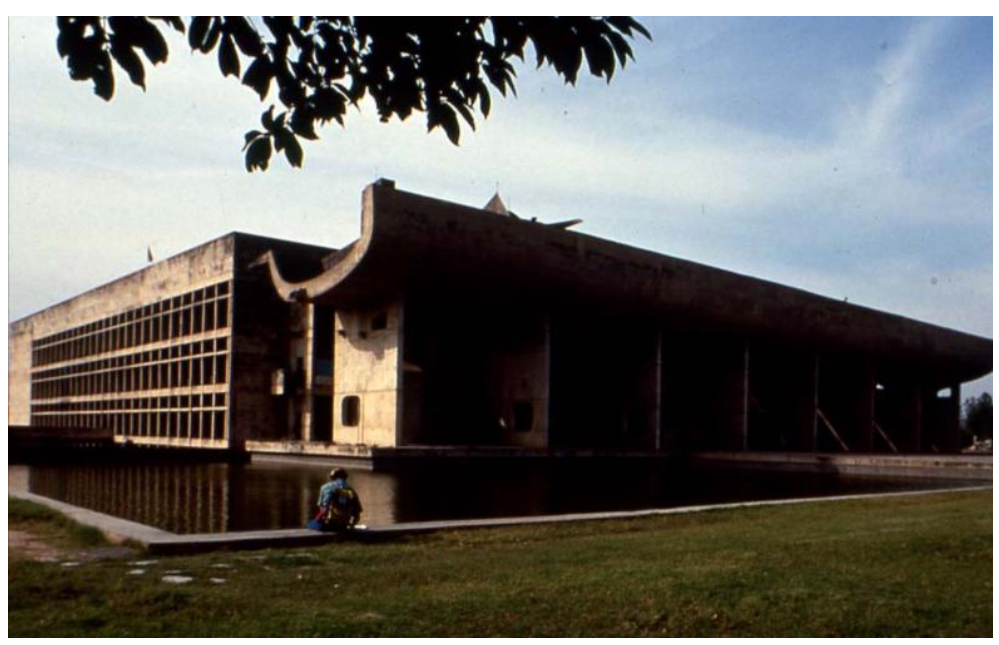

10. Le Corbusier, Parliament of Chandigarh, (AF archives).

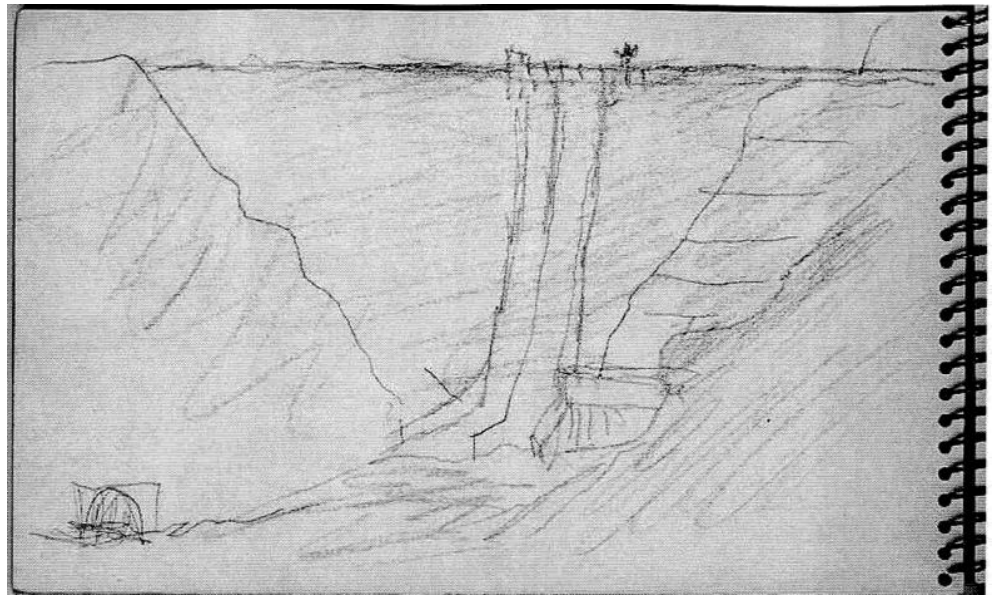

11. Le Corbusier, sketch of Bhakhra Dam, Carnet M52 (CFLC-ADAGP W1-4 086) 


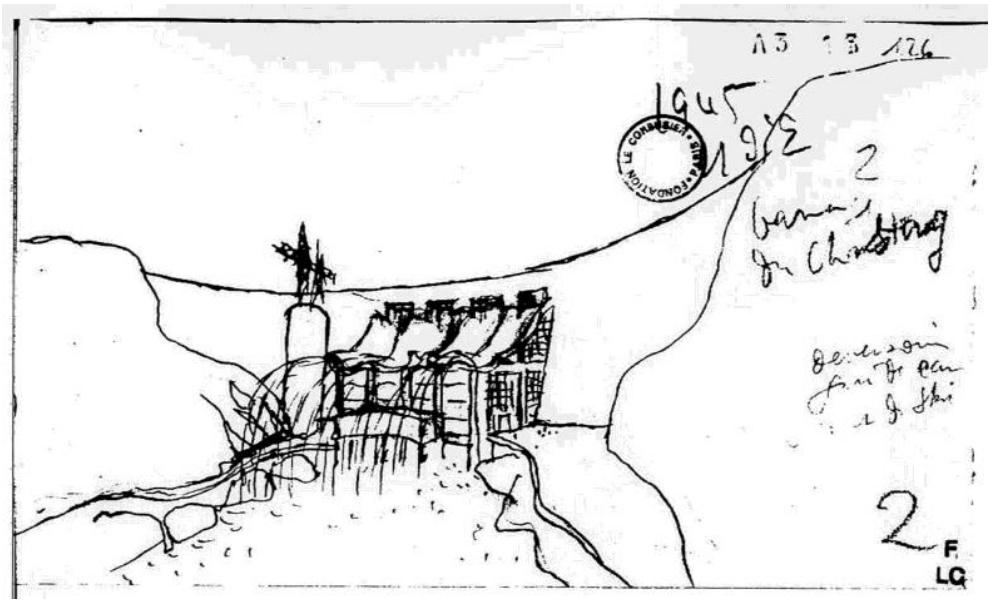

12. Le Corbusier, sketch of Chastang Dam, (CFLC-ADAGP A3-18 126).

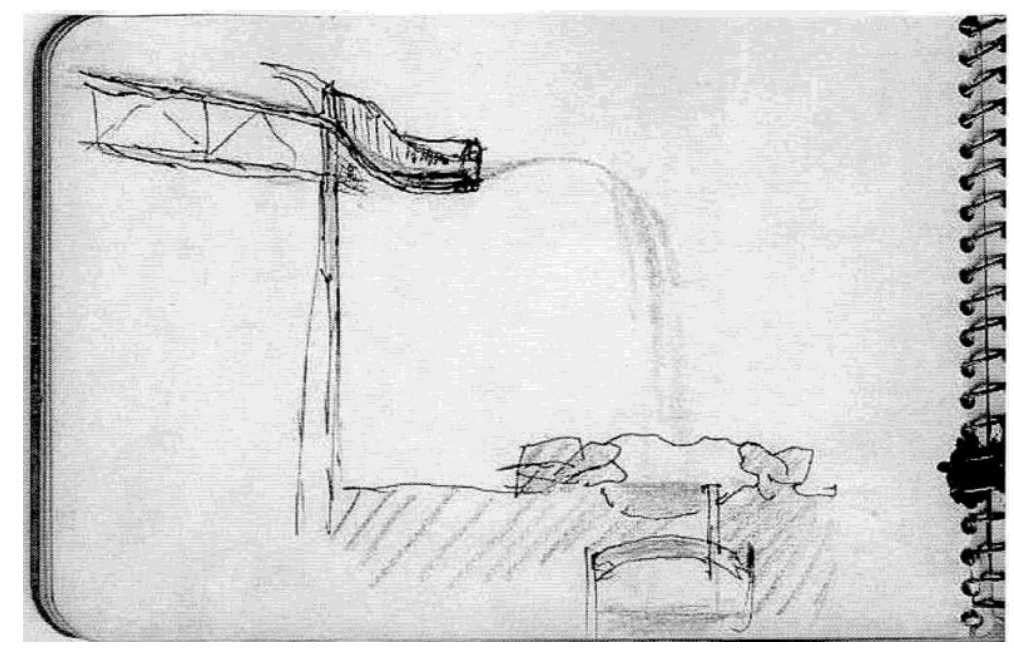

13. Le Corbusier, sketch of the gargoyle of Ronchamp Carnet E18 (CFLC-ADAGP W1-2 327)

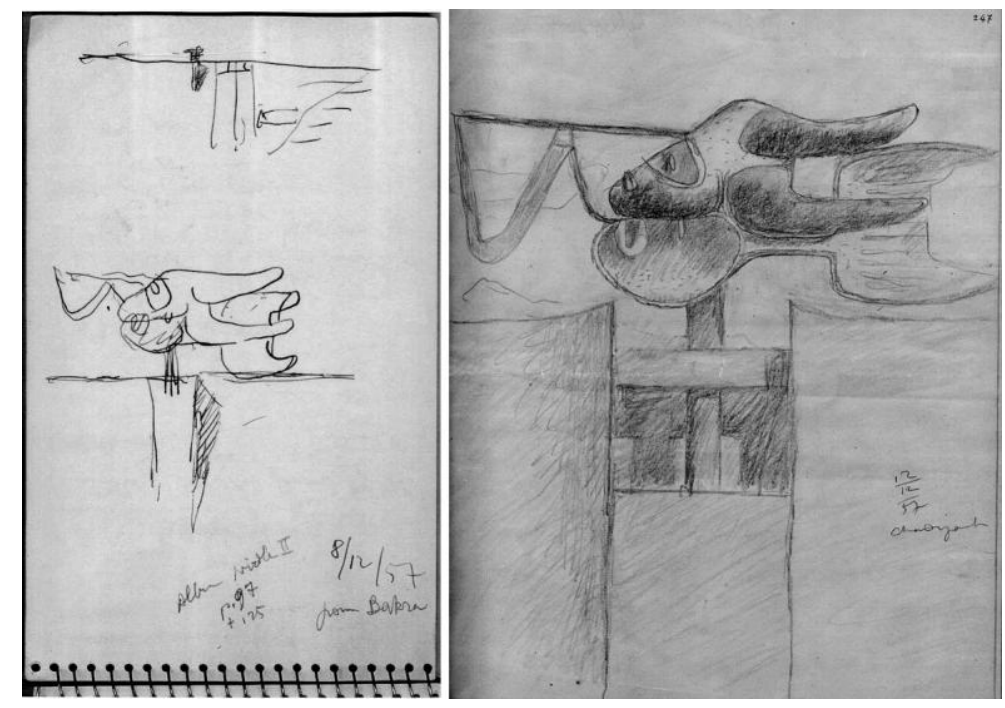

14. Le Corbusier, "naissance du taureaux" on the summit of Bhakhra Dam, 1957, Carnet M52 (CFLC-ADAGP W1-3 1088). 


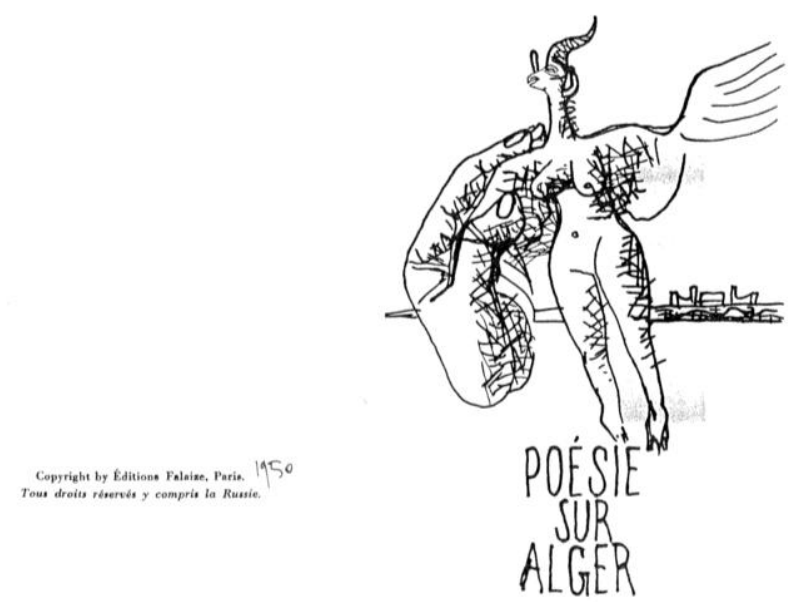

15. Le Corbusier, Poésie sur Alger, 1950.

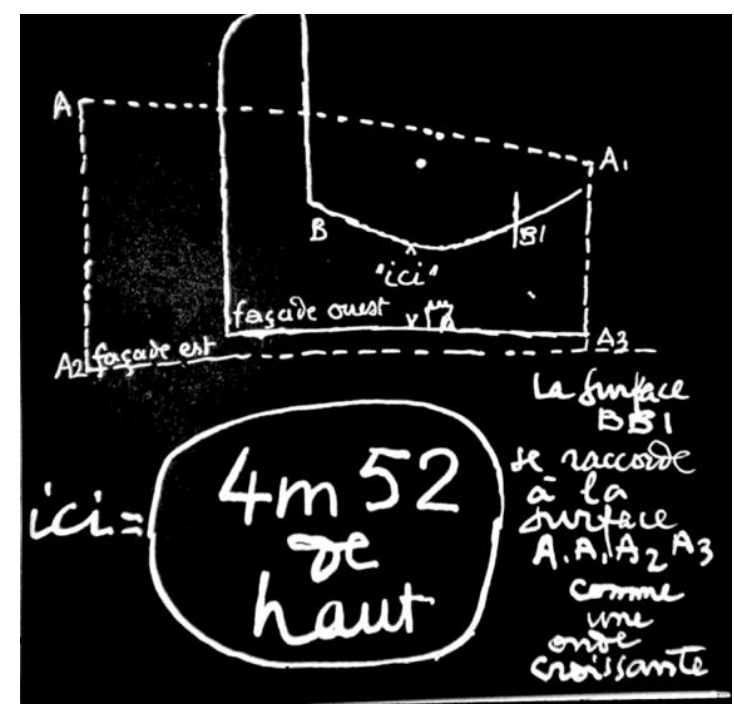

16. Le Corbusier, Textes et dessins pour Ronchamp, 1965, p. 39.

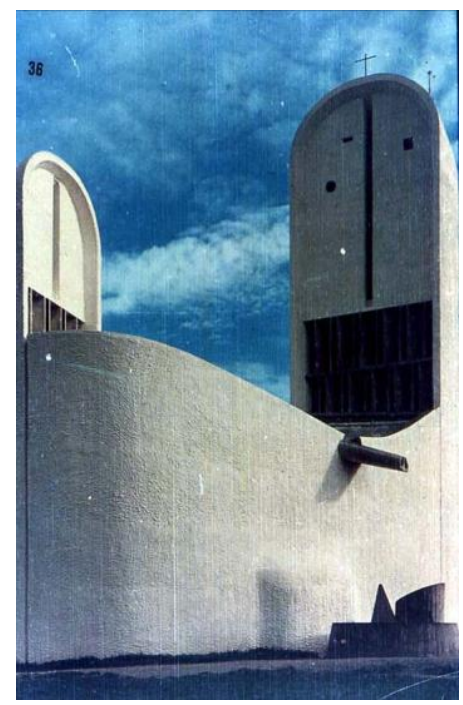

17. Le Corbusier, Ronchamp, (AF Archives). 


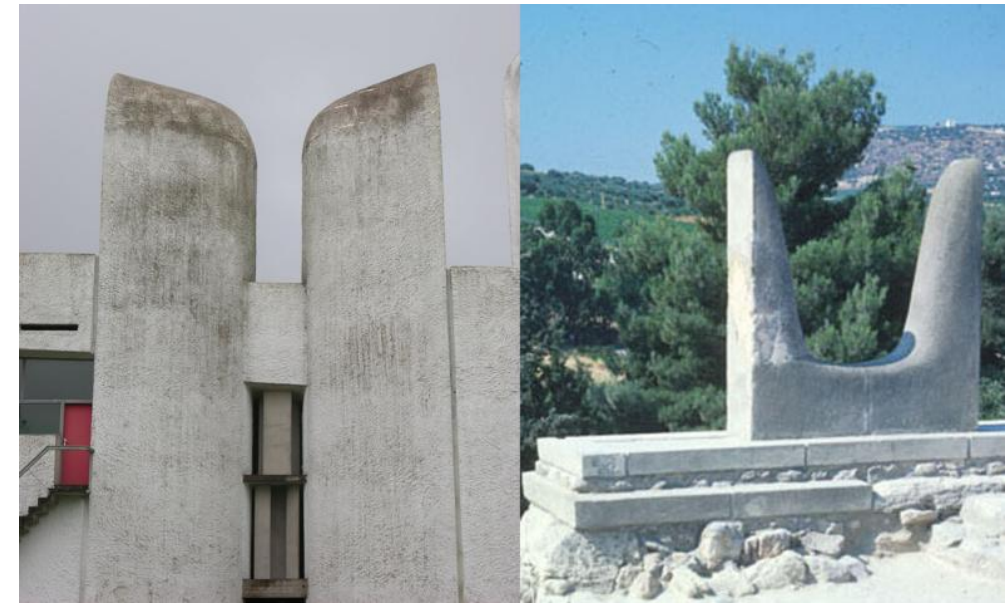

18. Le Corbusier, Ronchamp Northern facade; detail of the palace of Knossos. (AF Archives).

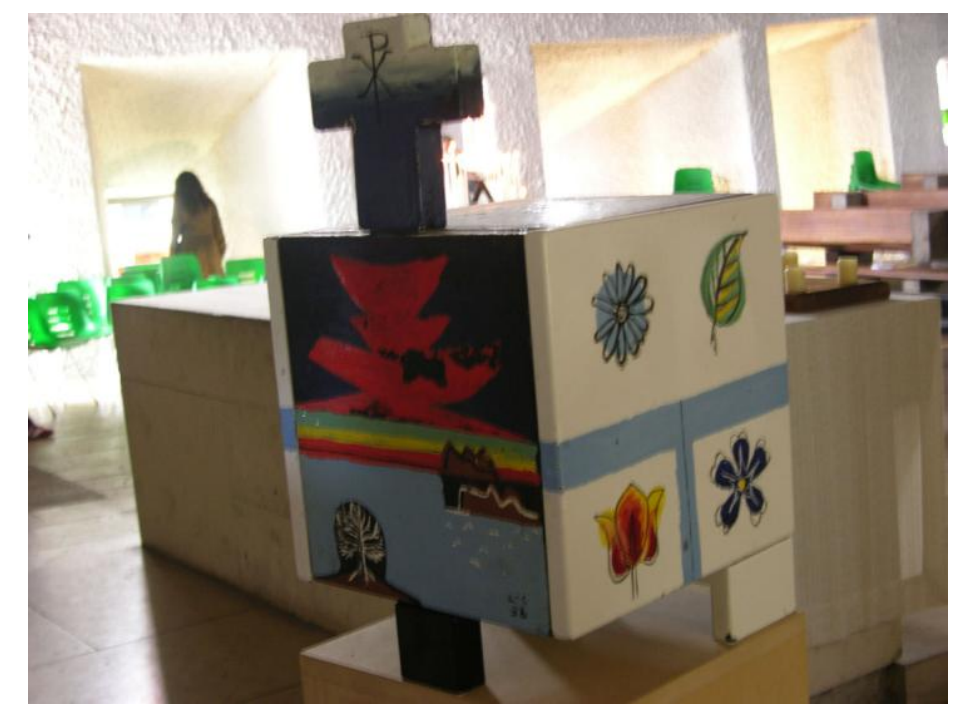

19. Le Corbusier, tabernacle of Ronchamp, 1958, (AF Archives).

\section{Conclusions}

In the essential opposition between nature and architecture, Le Corbusier assigns the male gender to architecture, made up of orthogonal planes, and the female gender to nature, which is curved. Since he assigns a female character to river beds too, the dam acquires symbolic value as the union of nature and architecture, confirmed by the natural tree form, hence female, set within the male outline. But more than this by the project of the great sculpture derived from the "birth of the bulls". This is the strong symbolic value of the Bhakra dam, the first element of the Cyclopean water channelling and power generation project for northern India, from the Bay of Bengal to the Arabian Sea. In the words of President Nehru Bhakra was the new temple of resurgent India, the symbol of India's progress. Nerhu also defined Chandigarh as the 'temple of the new India'.

The civil sacredness of Chandighar and Bhakra and the religious sacredness of Ronchamp come together in the faces of the tabernacle, just as they were joined together in Le Corbusier's original culture, that of the Cathar community of Chaux des Fonds, imbued with the ideal of social engagement as the expression of the humanitarian and social Christian mission which is the hallmark of the Cathar heresy. 
The symbolic relationship between Chandigarh, Ronchamp and its mystery of the Virgin Mary is confirmed by the stained-glass windows where the moon of Chandigarh - that in which for the first time in his life Le Corbusier detected the traits of a human visage - is joined to what can be nothing other than the stylised drawing of a female sexual organ, commented by the words 'Mother of God'. Mary's role as the mother of God is associated with the moon, which physiologically regulates maternity, but also with the sexuality denied by the mystery of immaculate conception of Mary, who is a woman only as a 'virgin and mother' (Fig. 20).

The new bell of Ronchamp, designed by Le Corbusier and made by Jean Prouvé, bears the names of Amelie, Charlotte, Yvonne (grandmother, mother and wife) and Marie. Le Corbusier's entire experience of the feminine resounds in Ronchamp, celebrating - besides the mother of God - the sacred female nature of Mother Earth and of Life. But it would be an omission not to quoting the monologue of Icarus' Ghost in Gide's Theseus, dedicated by Le Corbusier to the dying Yvonne: "Mais la raison de tout cela, Dieu limpide? de tant de peines, de tant d'efforts. Et vers quoi? La raison d'être? Et de chercher à tout des raisons? Vers quoi tendre, sinon vers Dieu? Comment se diriger? Où s'arrêter? Quand pouvoir dire: ainsi soit-il; rien ne va plus? Comment atteindre Dieu?, partant de l'homme? Si je pars de Dieu, comment parvenir jusqu'à moi? Cependant, tout autant que Dieu m'a formé, Dieu, n'est-il pas créé par l'homme? C'est à l'exacte croisée des cheimns, au coeur même de cette croix, que mon esprit veut se tenir",35.

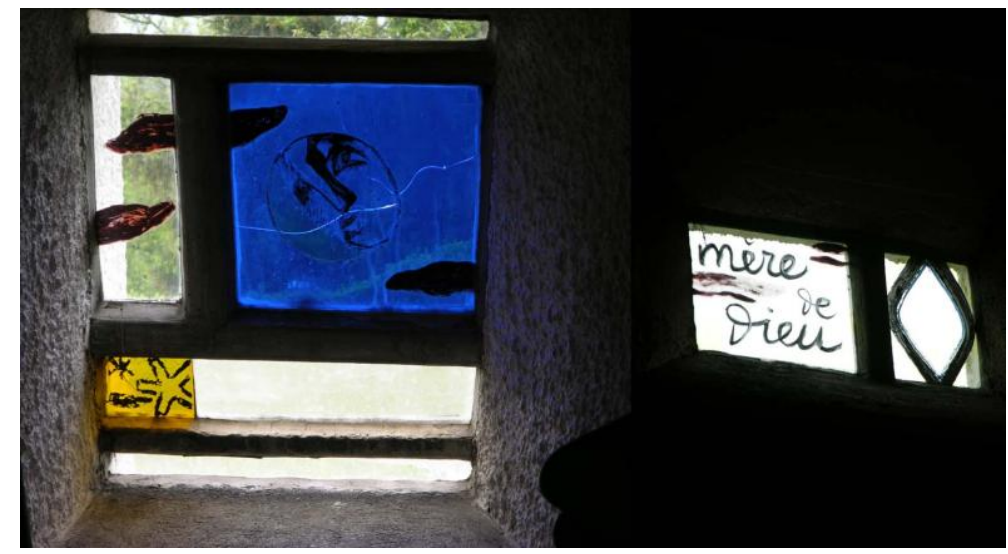

20. Le Corbusier, windows of Ronchamp, (AF Archives).

\section{Bibliography}

Calasso, Roberto: Le nozze di Cadmo e Armonia, Milano: Adelphi, 2005.

Casali, Valerio: "Le Corbusier, Josephine Baker e il Music-Hall”, in Massilia, Sant Cugat del Vallés (ES): Associaciò d'idees. Centre d'investigacion Estètiques, 2004.

Coll, Jaime: "Le Corbusier. Taureaux: an analysis of the thinking process in the last series of Le Corbusier's plastic work", in Art History, vol. 18, n. 4. December 1995, Oxford and Cambridge (Mass): Blackwell Publisher.

Cocteau, Jean: “Le secret professionnel”, in Poésie critique, vol. 1, Paris: Gallimard, 1959.

\footnotetext{
35 "But what is the reason for all that, limpid God? For so many pains, so many efforts. And all for what? What is the reason for being? And for seeking reasons for everything? Where are we to turn if not toward God? How are we to direct our steps? Where are we to stop? When can we say: so be it, nothing more to be done? How can we reach God, after starting from? And if I start from God, how can I reach out to myself? And yet, just as God formed me, isn't God created by man? It is at the exact crossroads, heart of that cross, that my mind wants to linger" (author's translation) Gide, André: Theésée, Paris: Gallimard, 1947; italian ed. Thésée, Bari: Palomar, 1996, p. 85-87.
} 
Gide, André: Theésée, Paris: Gallimard, 1947; italian ed. Thésée, Bari: Palomar, 1996.

Kerényi, Karl: Labyrinth-Studien, Zurich: Rhein-Verlag, 1950; italian ed. Nel labirinto, Torino: Boringhieri, 1983.

Kerenyi, Karl: Dionysos. Urbild des unzerstörbaren Lebens, München-Wien: Langen-Müller, 1976; italian ed. Dioniso, Milano: Adelphi, 1992, passim.

Kustrup, Mogens: "La peinture du silence", in Massilia, Sant Cugat del Vallés (ES): Associaciò d'idees. Centre d'investigacion Estètiques, 2005.

Jencks, Charles: Le Corbusier and the Continual Revolution in Architecture, New York: Monacelli Press, 2000; italian ed. Le Corbusier e la rivoluzione continua in architettura, Milano: Jaka Book, 2002.

Le Corbusier, Poème de l'Angle Droit, Paris: Éditions Tériade, 1955.

Jornod, Naima; Jornod, Jean-Pierre: Le Corbusier. Catalogue raisonné de l'oeuvre peint, vol. II, Milan: Skira, 2005.

Le Corbusier, "En Grèce, à l'échelle humaine", in Le voyage en Gréce, Paris: Cahiers périodiques, 1939.

Le Corbusier, Poésie sur Alger, Paris: Éditions Falaize, 1950.

Le Corbusier, Textes et dessins pour Ronchamp, Paris: Éditions Forces Vives, 1965.

Nietzsche, Friederich: Ecce Homo, Leipzig: Insel Verlag, 1908; italian ed. Ecce Homo, Milano, Adelphi, 16th ed., 2012.

Sanchez-Pombo, Marina: "La arquitectura de los fluidos. Le Corbusier y los rios", in Massilia, Sant Cugat del Vallés (ES): Associaciò d'idees. Centre d'investigacion Estètiques, 2004.

Schuré, Edouard: Le Grands Initiés. Esquisse de l'histoire secrète des religions, Paris: Perrin et Cie, 1889, passim.

Stirling, James: "Ronchamp; Le Corbusier's Chapel and the Crisis of Rationalism", in Architectural Review, 119, March 1956. 